\author{
Waldemar Stefan Tarczyński \\ University of Szczecin, Faculty of Economics and Management, Institute of Finance, \\ wtarc@uoo.univ.szczecin.pl
}

\author{
Małgorzata Ludmiła Tarczyńska-Łuniewska \\ University of Szczecin, Faculty of Economics and Management, \\ Institute of Econometrics and Statistics, maluni@poczta.fm
}

\title{
Application of The Leading Sector Identification Method in The Portfolio Analysis
}

\begin{abstract}
The development of the stock market requires taking into account the impact of many factors. Knowledge of the entire market is a result of research at different levels of aggregation. Referring to sectors, it should be stated that the level of economic development and financial sector shapes the picture of economic and market conditions being a derivative of development level of the entities forming the market. Therefore, the possibility of identification of leading sectors or companies that have the greatest impact on the market becomes significant. This approach is important due to several reasons. One of them is the process of investing in the capital market. Thus, the main objective of the study is to provide methods of identifying the leading sector in the capital market and the use of this information in the procedure of building a portfolio of securities. The study was carried out for the Warsaw Stock Exchange in 2006-2010. Certain information in the field of fundamental factors was utilized in the analysis. Selected factors were used for the construction of the dynamic fundamental power index FPI. This paper proposes a simple method of determining the leading sector. The method takes into account information about the fundamental strengths of companies forming a sector and the number of companies comprising a given sector. Based on this information, a procedure of building a portfolio of securities was proposed. At the beginning of 2011 two types of portfolios were constructed and their effectiveness for 2011-2016 (26 IX) was verified. As a result of the research the hypothesis that selection of securities to portfolio using the leading sector identification method is better than the classical methods of portfolio analysis was proven.
\end{abstract}

Keywords: fundamental analysis, fundamental power index, capital market

JEL: G11, G31 


\section{Introduction}

In classical terms, long-term investing on stock exchange can be carried out using methods of portfolio or fundamental analyzes. Recently, a combination of these two groups of analyzes, in order to improve the efficiency of investment, can be observed in the reference literature. In diversification of horizontal and vertical risks, the problem is heavily exposed. Due to the nature of the long-term investments and changes in the stock market investors, analysts and researchers continue to seek new and innovative tools that make modifications to existing ones, in order to reduce the risk of investing. The sectoral approach may also be applied as a part of risk diversification and the structure of the securities portfolio. Sectoral analysis of the portfolio and sectoral diversification of risk in the capital market can be carried out following at least two approaches:

1) the securities portfolio is structured from companies selected as representatives of sectors;

2) the portfolio of securities is structured from companies selected from sectors leading on the market.

In the paper, the second approach was considered with regard to the structure of securities portfolio. However, at first, this approach requires identifying the leading sectors. It is assumed that leading sectors are the guarantee for investors to obtain the above-average profits on the stock exchange. Including the strength of a sector in the investment process can reduce the risk of investment in securities. In the paper a hypothesis was formulated, that selection of securities to portfolio using the leading sector identification method is better than the classical methods of portfolio analysis.

The main goal of this article is to apply the leading sector identification method in portfolio analysis. To achieve the set objective it is required to identify the leading sectors on the Warsaw Stock Exchange and to use this information in construction of the sectoral securities portfolio. The article proposes an objective and simple procedure of identification of the leading sector that allows for ranking sectors according to their investment attractiveness. This approach should contribute to higher efficiency of portfolio analysis in practice and significantly reduce the risk of investments in securities. To identify a leading sector, the concept of fundamental power index has been employed. Due to this approach the measurement of the fundamental strength (attractiveness) has become possible.

The Markowitz classic and modified model were applied in the formal construction of portfolio of securities. The research was conducted for companies listed on the Warsaw Stock Exchange (WSE). The analysis covered period 20062016. In addition, in development of fundamental power index (FPI) information on selected economic and financial factors was utilized. 


\section{The concept and design of Fundamental Power Index $(F P I)$}

The fundamental strength of a company is a concept closely related to the fundamental analysis, which identifies the company's economic and financial standing. Sources of fundamental strength concept must be sought in the financial analysis. Benjamin Graham (Graham, Dodd, 2005; Graham, 2007) is considered to be the first to use methods of fundamental analysis in the investing process. The concept of fundamental strength developed in the literature, often without being called so. Many practical applications of using fundamental analysis this way can be found in the following works: Hagstrom, 2007; Tarczyński, Łuniewska, 2004; Arnold, 2010; Navellier, 2007; Mauldin, 2007; Blajer-Gołębiewska, 2012; 2014; Mrzygłód, Nowak, 2013; Bodie, Kane, Marcus, 2014; Arnott, Hsu, West, 2008; Edirisinghe, Zhang, 2008; Ou, Penman, 1989; Piotroski, 2000; Holthausen, Larckrer, 1992; Abad, Thore, Laffarga, 2004.

Please note that the fundamental force is composed of two kinds of factors:

1) external - macroeconomic data coming from the economy;

2) internal - microeconomic information from the companies.

Factors in both groups may be quantitative and qualitative. Quantitative factors, directly measurable, are easier for consideration. Qualitative factors, which for example allow assessing the economic situation of the country, can be taken into account using zero - one variables. The fundamental strength can be considered in two ways:

1) as a result of the analytical operations (including measurement) carried out under phases of fundamental analysis, but without valuation - fundamental analysis, non-classical, simple approach;

2) fundamental strength as the internal value, which is the sum of all the factors affecting the value in accordance with all phases of fundamental analysis, complex approach.

The above considerations lead to two definitions, (Tarczyńska-Łuniewska, 2013b):

1. The fundamental strength of an economic entity as a total entity's assessment category based on all the areas of its operation (macro and micro), according to the phases of fundamental analysis. Includes also the valuation process and the value of (internal) economic entity, in terms of the complex approach.

2. The fundamental strength of an entity as a category of evaluation focused on its economic and financial standing, which is the result of the effects of the operation, where it is impossible to achieve a good financial standing, if other factors and areas of operation work improperly.

Such a definition of the fundamental strength determines the method of FPI construction. Within this area, various approaches are possible. At first, meas- 
urement of the fundamental strength requires the knowledge of its nature and the areas of its formation. Generally, the base of the fundamental strength of companies lies in the fundamental analysis. Therefore, this means that the fundamental strength and FPI are closely related. The index is a multidimensional category, directly immeasurable, which can be defined as a synthetic variable, taking into account the impact of quantitative and qualitative factors in the company, as well as the internal and external factors, within which the company operates on the market. Tarczyński was the precursor of the fundamental strength measurement. The idea of the synthetic measure of development has been used in his concept. In his works, in the stocks analysis, Tarczyński took into account the economic and financial situation of companies, which formed the basis for the evaluation of their fundamental strength. The concept of such an approach to fundamental strength and its measurement has been introduced into Polish literature by this author, (Tarczyński, 1994a; 1995a; 1995b). In addition, this concept drew attention to the issue of fundamental analysis as a source of fundamental strength of the company. A key element in the discussion on measurement of the fundamental forces was the use of certain stages of fundamental analysis, which allowed the analysis and evaluation of the economic and financial standing of a company. This assumption took into account that through the prism of economic and financial standing one can see all the effects of the company's operation on the market. The concept of the fundamental strength and its measurement has been developed by Tarczyńska-Łuniewska. In 2013 the scientific publication on the methodology of formation and measuring of the fundamental strength was elaborated (Tarczyńska-Łuniewska, 2013b).

The procedure of construction of the Fundamental Power Index FPI is not complicated, but requires consideration of certain elements:

1) adoption of one of the definitions given above;

2) identification of the most important factors responsible for the creation of fundamental strength;

3) obtaining data from fundamental analysis at the micro or macro level? which is dependent on the adopted method of FPI index construction.

The fundamental power index, like the concept of fundamental strength of a company can take into account different types of information which come directly from the company or from the outside but have an impact on functioning of the company. It should be emphasized that this information comes from? quantitative and/or qualitative factors responsible for creation of the fundamental strength. Generally, quantitative factors have the advantage over qualitative factors because they are directly measurable and, naturally, can be a variable in the construction of the FPI. It is often explained that the nature of quantitative factors is identified with their greater objectivity of contained information. Qualitative factors, due to their nature, are questionable and their meas- 
urement is difficult. Factors of that group are biased by subjectivity. Their direct application to FPI is difficult, and often simply impossible due to the impossibility to describe them in a measurable form. However, this does not diminish their importance and impact on the development of the fundamental strength of a company. Therefore in the construction of the FPI it is easier to take into account the quantitative factors that can be directly included in the measurement of the fundamental strength. Therefore, in terms of fundamental strength and the question of its measurement it is worth using only the economic and financial ratios, which, de facto, reflect the effects of impacts of qualitative and macroeconomic factors.

\subsection{Formal construction of FPI}

The construction of the FPI is based on multidimensional measures. In the measurement process, factors of fundamental strength are the diagnostic variables constituting a base for index construction. The methodology of the construction of fundamental strength makes the index itself not reasonably stable in terms of variables that can be used for the construction of measurement. This means that the analyst can every time create their own set of variables according to the adopted approach. However, it becomes superior to the variables within the scope of the areas of the formation of a company's fundamental strength. It is worth to emphasize that in the construction of the FPI one can take advantage of the stability of fundamental strength factors in time and space. This refers to existing standards for economic and financial ratios (variables) or to maintaining the stability of the indicators' level for the company over time. Thus, there are several possibilities to build the fundamental power index:

1) with or without consideration of the fundamental strength factors' stability in time and space;

2) selection of the type of fundamental strength factors for the index construction,

3) the use of the idea of synthetic measures of development,

4) the use of scoring methods in the process of index construction.

The analyst chooses the method of index construction, which is the most valuable from the study objective's point of view. It is also associated with the use of tools during the construction of the index (e.g.: MATLAB or EXCEL). Formal steps of FPI construction:

1. Defining a set of diagnostic variables according to the accepted definition of the fundamental strength.

2. Application of selected methods to determine the level of the fundamental strength of the analyzed companies.

3. Calculation of FPI: 


$$
\begin{gathered}
F P I_{j}=w_{Q} \cdot Q_{j}+w_{F S} F S_{j}, \\
w_{Q}=n_{Q} / N, w_{F S}=n_{F S} / N, \\
w_{Q}+w_{F S}=1,
\end{gathered}
$$

where:

$i-i$-factor of the fundamental strength (financial and economic index), $i=1,2$, $\ldots, N$;

$j$-j-company, $j=1,2, \ldots, l$;

$F P I_{j}$ - fundamental power index for $j$ company;

$w_{Q}$ - weight for qualitative factors;

$w_{F S}-$ weight for quantitative factors;

$N$ - number of all variables included in the index structure;

$n_{Q}$ - number of qualitative variables;

$n_{F S}-$ number of quantitative variables;

$Q_{j}$ - fundamental power index for $j$ company, constructed for quantitative factors;

$F S_{j}$ - fundamental power index for $j$ company constructed for quantitative factors.

This paper presents the structure of FPI based on the idea of scoring methods in the dynamic perspective. The dynamic approach means that the fundamental strength of the company is perceived through the prism of the level of economic and financial indices obtained at a specific time. According to the assumption of the fundamental analysis, the company's evaluation over time should take into account information in the historical period (3-5 years prior to analysis). If this condition is met, the index has a dynamic nature. Within the structure of the index it is worth to consider the stability of indices over time. Then for the construction of the index using quantitative factors, the idea of building a database applies, stable over time:

where:

$$
F P I_{j}=S F_{j},
$$

$F P I_{j}$ - fundamental power index for $j$ company including only quantitative variables;

$S F_{j}$ - dynamic, quantitative fundamental power index for $j$ company, including $i$ internal fundamental factors.

Having included the dynamic nature of the index, the result is as follows:

$$
F P I_{j}=S F_{j}=\sum_{i=1}^{N} \sum_{t=1}^{n} w_{t} \cdot x_{i t}
$$

where $x_{i t}$ are values of the fundamental power indices (economic and financial indices, $i$ index over $t$ period), and weights are determined according to the following formula: 


$$
w_{t}=\frac{m_{t}}{\sum_{t=1}^{n} m_{t}}, \quad \sum_{t=1}^{n} w_{t}=1, w_{t} \geq 0
$$

where:

$t=1,2, \ldots, n$;

$w_{t}-$ weight for $t$ period and $i$ factor;

$m_{t}$ - order of $i$ index over the analyzed period (the oldest periods have the lowest value), the order of periods is analogous for all the factors;

the other symbols - the same as in formulas (1)-(3).

Table 1. The value of points awarded for selected financial and economic ratios

\begin{tabular}{|c|c|c|c|}
\hline The name of indicator & $\begin{array}{l}\text { The norm } \\
\text { of indicator }\end{array}$ & Points & $\begin{array}{c}\text { The maximum number } \\
\text { of points }\end{array}$ \\
\hline Current ratio & $<1.2 ; 2>$ & $\begin{array}{l}\text { Below } 1.2-0 \\
\text { from } 1.2 \text { to } 1.4-3 \mathrm{p} \\
\text { above } 1.4 \text { to } 1.6-4 \mathrm{p} \\
\text { above } 1.6 \text { to } 2-6 \mathrm{p} \\
\text { above } 2-4 \mathrm{p}\end{array}$ & 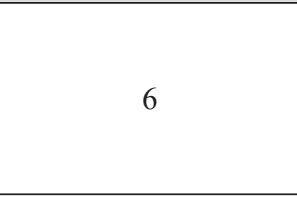 \\
\hline $\begin{array}{l}A A I \\
\text { (average age inven- } \\
\text { tory) }\end{array}$ & $\begin{array}{c}<30 ; 60> \\
\text { (days) }\end{array}$ & $\begin{array}{c}\text { below } 30-6 \mathrm{p} \\
\text { from } 30 \text { to } 40-4 \mathrm{p} \\
\text { above } 40 \text { to } 50-3 \mathrm{p} \\
\text { above } 50 \text { to } 60-2 \mathrm{p} \\
\text { above } 60-0 \mathrm{p}\end{array}$ & 6 \\
\hline $\begin{array}{l}A C P \\
\text { (average collection } \\
\text { period) }\end{array}$ & $\begin{array}{c}<30 ; 60> \\
\text { (days) }\end{array}$ & $\begin{array}{c}\text { below } 30-6 \mathrm{p} \\
\text { from } 30 \text { to } 40-4 \mathrm{p} \\
\text { from } 40 \text { to } 50-3 \mathrm{p} \\
\text { from } 50 \text { to } 60-2 \mathrm{p} \\
\text { above } 600 \mathrm{p}\end{array}$ & 6 \\
\hline$R O A$ & $>0$ & $\begin{array}{l}\text { above } 0 \text { to } 0.2-2 \mathrm{p} \\
\text { above } 0.2 \text { to } 0.4-4 \mathrm{p} \\
\text { above } 0.4-6 \mathrm{p}\end{array}$ & 6 \\
\hline$R O E$ & $>0$ & $\begin{array}{l}\text { above } 0 \text { to } 0.2-2 \mathrm{p} \\
\text { above } 0.2 \text { to } 0.4-4 \mathrm{p} \\
\text { above } 0.4-6 \mathrm{p}\end{array}$ & 6 \\
\hline Debt ratio & $<0.5 ; 0.9>$ & $\begin{array}{c}\text { below } 0.5-6 \mathrm{p} \\
0.51-0.6-5 \mathrm{p} \\
0.61-0.7-4 \mathrm{p} \\
0.71-0.8-3 \mathrm{p} \\
0.81-0.9-1 \mathrm{p} \\
\text { above } 0.9-0 \mathrm{p} \\
\end{array}$ & 6 \\
\hline
\end{tabular}

Source: Tarczyńska-Łuniewska, 2013b

Using the scoring method, the level of scores for the factors taken into account in the design of the indicator must be established (see Tab. 1). In this regard, for 
applied economic and financial indices one can follow the existing general or sectoral standards. The analyst may also determine individual standards for indices using statistical methods. The fundamental power index, stable over time and using a scoring method can be described as follows:

$$
F P I_{j}=\sum_{i=1}^{N} \sum_{t=1}^{n} w_{t} \cdot P_{i t},
$$

where:

$i, j, t$ - the same as in the above formulas;

$F P I_{j}$ - fundamental power index for $j$ company, constructed following the scoring method;

$P_{i t}$ - number of scores for $i$ factor in $j$ company, over t period;

$w_{t}$ - weight for $i$ factor over $t$ period, the same as in formula (6).

The level of $F P I_{j}$ determined by the scoring method can be considered as a measure of the fundamental strength because it takes into account the sum of the weighted points for the fundamental factors. Established weights emphasize the importance of the given factor over time (factors closest to the current period included in the study have the highest weight). Determination of the maximum number of scores for each factor allows establishing the maximum level of fundamental power index for scoring method. Taking into account the information presented in Table 1 a company can reach the level of $S F_{j}$ at maximum 36 points. The higher sum of all points for all factors indicates the higher level of fundamental strength.

\section{Identification of the leading sector on the Warsaw Stock Exchange}

In order to determine the sectoral fundamental power index, the FPI index calculated according to the formula (7) was used. After determining the FPI for each company, they were divided into sectors. Then for each sector the sectoral fundamental power index SFPI was determined according to the formula:

where:

$$
S F P I_{s}=\sum_{j=1}^{l}\left(F P I_{s j} \cdot v_{j}\right),
$$

$S F P I_{s}$ - fundamental power strength for $s$ sector;

$s$ - number of sectors, $s=1,2, \ldots, S$;

$v_{j}$ - weight for fundamental power index for $j$ company in $s$ sector. 
Weights for the fundamental power index for a given company were determined according to the following formula:

$$
v_{j}=\frac{F P I_{j}}{\sum_{j=1}^{l} F P I_{j}}, v_{j} \geq 0, \quad \sum_{j=1}^{l} v_{j}=1 .
$$

The proposed system of weights allows one to take into account individual impact of each individual company on the fundamental power index in a sector and allows for the consideration of impact of indicators significantly deviating from the average for the sector. Ranking of sectors is built on the basis of sectoral fundamental power index SFPI defined by formula (8). The sector that has the highest value of this index is the strongest one.

To illustrate this procedure in practice, companies listed on the Main Market of the Warsaw Stock Exchange were analyzed. The study covered 203 companies over the period 2006-2010. These were all companies listed continuously on the Main Market from 2006 to 2010 and for which all economic and financial data that allow for the application of the proposed research procedure were available. Economic and financial indices presented as annual data were used in the procedure. Commonly available indices used by analysts and experts in the evaluation of economic and financial standing of companies were employed. The indicators come from four groups: profitability, liquidity, management efficiency and debt. The following indices were considered in each group:

1) Profitability: the return on equity $(R O E)$ and return on assets $(R O A)$ - the indices have no standards, value should be above zero, the higher the better;

2) Liquidity: current liquidity ratio, the standard is within the range from 1.2 to 2 ;

3) Management efficiency: rotation of liabilities in days, receivables rotation in days (for both, the standard range is 30 to 60 days, the level below 30 days is also assessed positively);

4) Debt: debt ratio, the standard value is from 0.5 to 0.9 , an index lower than 0.5 is also assessed positively;

The selection of indices for the presentation of the proposed approach was based on (Tarczyński, 1994b: 266-268). The values of these indices are presented in Table 1. In addition, Table 1 includes points allocated to individual companies, dependent on the ratio used in the scoring assessment of a company to determine the fundamental power index. In the scoring method, the approach discussed in detail in (Tarczyńska-Łuniewska, 2013b: 206-214) was adopted. Table 2 presents the number of companies in each of the analyzed sectors, and Table 3 provides SFPI values for each sector determined by formula (8).

Data in Table 2 shows that the sectors of construction engineering and electrical engineering industry are the most numerous, while telecommunications and 
fuel industry have the lowest number of companies. The best (leading sectors) in 2006-2010 in terms of SFPI value are the following: IT, construction engineering and electrical engineering industry. On the other hand, the weakest are sectors of telecommunications and financial services. This means that the risk of investing in these sectors is the highest and considering the fundamental point of view, they should not be subject to the long-term investment. The dynamic nature of the determined measure (taking into account years 2006-2010) allows for the recognition of the results to be objective and reliable.

Table 2. Number of companies in sectors

\begin{tabular}{|l|c|l|c|}
\hline \multicolumn{1}{|c|}{ Sector name } & Number of companies & \multicolumn{1}{c|}{ Sector name } & Number of companies \\
\hline Construction & 27 & Electro-engineering & 21 \\
\hline Developers & 3 & Pharmaceutical & 5 \\
\hline Energy & 3 & Light Industry & 6 \\
\hline Finance - other & 1 & Building materials & 11 \\
\hline Retail & 14 & Metals & 13 \\
\hline Wholesale & 19 & Automobiles & 4 \\
\hline Hotels \& Restaurants & 4 & Oil \& Gas & 2 \\
\hline IT & 24 & Food & 15 \\
\hline Media & 6 & Plastics materials & 5 \\
\hline Chemicals & 3 & Telecom & 1 \\
\hline Wood \& Paper & 6 & Services - other & 10 \\
\hline
\end{tabular}

Source: own calculations

\section{Construction of the sectoral portfolio of securities}

Based on data presented in Table 3 and 7 leading sectors identified by the Sectoral Fundamental Power Index (the value of SFPI index of these sectors is above one, which significantly exceeds the level of measurement for the other sectors) were selected. It was agreed that the database of companies for the construction of the portfolio will consist of 20 companies, which led to the following formula for calculation of the number of companies in selected sectors, which would entered the database:

$$
n_{R}=\frac{n_{S}}{N} \cdot 20
$$

where:

$n_{R}-$ number of companies selected for a given sector to be entered into the database;

$n_{s}$ - number of companies in a sector listed on WSE;

$N$ - total number of all companies included in 7 selected sectors. 
Table 3. SFPI values for the surveyed sectors in 2006-2010

\begin{tabular}{|l|c|}
\hline \multicolumn{1}{|c|}{ Sector } & SFPI \\
\hline$I T$ & 1.77 \\
\hline Construction & 1.72 \\
\hline Electro-engineering & 1.60 \\
\hline Retail & 1.14 \\
\hline Wholesale & 1.13 \\
\hline Metals & 1.13 \\
\hline Food & 1.01 \\
\hline Services - other & 0.74 \\
\hline Building materials & 0.71 \\
\hline Light Industry & 0.50 \\
\hline Wood \& Paper & 0.48 \\
\hline Media & 0.45 \\
\hline Hotels \& Restaurants & 0.41 \\
\hline Pharmaceutical & 0.41 \\
\hline Plastics materials & 0.34 \\
\hline Developers & 0.26 \\
\hline Automobiles & 0.26 \\
\hline Energy & 0.19 \\
\hline Chemicals & 0.19 \\
\hline Oil \& Gas & 0.19 \\
\hline Telecom & 0.08 \\
\hline Finance - other & 0.07 \\
\hline & \\
\hline
\end{tabular}

Source: own calculations

Based on data from 2006-2016 two types of portfolios were constructed for such a database of companies, the classic model of Markowitz and fundamental portfolio of securities. Portfolios were constructed using the following formulas:

\section{Markowitz Model (MM)}

$$
\begin{gathered}
S_{p}^{2}=\sum_{i=1}^{k} \sum_{j=1}^{k} x_{i} \cdot x_{j} \cdot \operatorname{cov}\left(x_{i}, x_{j}\right) \rightarrow \min , \\
R_{p}=\sum_{i=1}^{k} x_{i} \cdot R_{i} . \\
R_{p}=R_{0}, \\
\sum_{i=1}^{k} x_{i}=1, \\
x_{i} \geq 0,
\end{gathered}
$$


where:

$S_{p}$ - portfolio's expected risk;

$R_{p}^{p}$ - portfolio's expected rate of return;

$R_{0}$ - desired rate of return;

$k$ - number of assets in a portfolio;

$x_{i}$ - asset i's share in the portfolio (necessary to determine $R_{p}$ and $S_{p}$ ).

2. Modified fundamental portfolio of securities (MFP)

$$
\begin{gathered}
S_{p}^{2}=\sum_{i}^{k} \sum_{j}^{k} x_{i} x_{j} \operatorname{cov}(i, j)\left(1-F P I_{i}^{*}\right)\left(1-F P I_{j}^{*}\right) \rightarrow \min , \\
F P I_{i}^{*}=\frac{F P I_{i}}{\sum_{i}^{k} F P I}, \\
\sum_{i}^{k} F P I_{i}^{*}=1, \\
R_{p}=R_{0}, \\
\sum_{i=1}^{k} x_{i}=1, \\
x_{i} \geq 0
\end{gathered}
$$

where:

$F P I_{i}-F P I$ value for $i$ company;

the other symbols as in (11).

A line of efficient portfolios was built for each type of portfolio - $M M$ and MFP. A line of efficient portfolios was started for $R_{0}=0.001$ till the solution didn't exist. The minimal value of $V_{p}$ was used to select the best portfolio (for each models: $M M$ and $M F P$ ):

$$
V_{p}=\frac{S_{p}}{R_{p}} .
$$

Table 4 contains the compositions of portfolios constructed in both variants. According to the structure of selected portfolios, hypothetical purchase of stocks took place on the first listing in 2011. Table 5 contains the actual rate of return on the portfolios and WIG20 index as a benchmark. Hypothetical sales were made on the last quotation in 2012-2015 and on 26.09.2016. Data in Table 5 shows that fundamentally strong sectors represented by their best companies offer increasingly higher rate of return over the course of time. This is $92 \%$ for $M M$ and $103 \%$ for the benchmark MFP 
(WIG20) $-38 \%$ over less than 6 years (5 years 9 months), which proves the validity? of the proposed approach. The average annual return rate is equal to $15 \%(M M)$ and $17 \%(M F P)$, respectively. It should also be noted that the results refer to the years 2011-2016 (IX), which were not good years for the market.

Table 4. The compositions of portfolios constructed in variants: MM, MFP

\begin{tabular}{|l|c|l|c|}
\hline \multicolumn{1}{|c|}{$\boldsymbol{M M}$} & Structure & \multicolumn{1}{c|}{ MFP } & Structure \\
\hline WADEX & 0.0462 & WADEX & 0.0549 \\
\hline OPONEO & 0.5320 & POLNA & 0.0001 \\
\hline STALPROF & 0.2503 & OPONEO & 0.5613 \\
\hline KGHM & 0.1147 & TIM & 0.0060 \\
\hline KRUSZWIC & 0.0569 & EFEKT & 0.0046 \\
\hline & & STALPROF & 0.2819 \\
\hline & & KGHM & 0.0001 \\
\hline & & KRUSZWIC & 0.0911 \\
\hline$V_{p}$ & 2.1817 & $V_{p}$ & 2.0926 \\
\hline$R_{p}$ & 0.0150 & $R_{p}$ & 0.0150 \\
\hline$S_{p}$ & 0.0327 & $S_{p}$ & 0.0314 \\
\hline
\end{tabular}

Source: own calculations

Table 5. A real rates of return for analyzed portfolios and WIG20 in 2011-2016 (IX)

\begin{tabular}{|l|c|c|c|c|c|c|}
\hline \multicolumn{1}{|c|}{$\boldsymbol{M M}$} & $\mathbf{3 0 . 1 2 . 2 0 1 1}$ & $\mathbf{2 8 . 1 2 . 2 0 1 2}$ & $\mathbf{3 0 . 1 2 . 2 0 1 3}$ & $\mathbf{3 0 . 1 2 . 2 0 1 4}$ & $\mathbf{3 0 . 1 2 . 2 0 1 5}$ & $\mathbf{2 6 . 0 9 . 2 0 1 6}$ \\
\hline WADEX & -0.0188 & -0.0079 & 0.0036 & -0.0295 & -0.0343 & -0.0274 \\
\hline OPONEO & -0.1936 & -0.2594 & -0.1254 & -0.1235 & 0.5351 & 1.1115 \\
\hline STALPROF & -0.1027 & -0.0718 & -0.0054 & -0.1101 & -0.1395 & -0.0935 \\
\hline KGHM & -0.0401 & 0.0135 & -0.0351 & -0.0412 & -0.0718 & -0.0654 \\
\hline KRUSZWIC & 0.0145 & -0.0331 & -0.0054 & -0.0084 & -0.0142 & -0.0081 \\
\hline $\boldsymbol{R}_{p}$ & -0.3405 & -0.3587 & -0.1678 & -0.3126 & 0.2752 & $\mathbf{0 . 9 1 7 1}$ \\
\hline $\boldsymbol{W I G 2 0}$ & -0.2292 & -0.0716 & -0.1371 & -0.1676 & -0.3318 & $\mathbf{- 0 . 3 7 4 6}$ \\
\hline \multicolumn{1}{|c|}{$\boldsymbol{M F P}$} & $\mathbf{3 0 . 1 2 . 2 0 1 1}$ & $\mathbf{2 8 . 1 2 . 2 0 1 2}$ & $\mathbf{3 0 . 1 2 . 2 0 1 3}$ & $\mathbf{3 0 . 1 2 . 2 0 1 4}$ & $\mathbf{3 0 . 1 2 . 2 0 1 5}$ & $\mathbf{2 6 . 0 9 . 2 0 1 6}$ \\
\hline WADEX & -0.0224 & -0.0093 & 0.0042 & -0.0350 & -0.0408 & -0.0325 \\
\hline POLNA & 0.0000 & 0.0000 & 0.0001 & 0.0001 & 0.0001 & 0.0001 \\
\hline OPONEO & -0.2042 & -0.2737 & -0.1323 & -0.1303 & 0.5646 & 1.1727 \\
\hline TIM & -0.0027 & -0.0033 & -0.0034 & -0.0029 & -0.0014 & 0.0007 \\
\hline EFEKT & -0.0025 & -0.0022 & -0.0022 & -0.0010 & 0.0010 & 0.0025 \\
\hline STALPROF & -0.1156 & -0.0808 & -0.0061 & -0.1240 & -0.1571 & -0.1053 \\
\hline KGHM & 0.0000 & 0.0000 & 0.0000 & 0.0000 & 0.0000 & 0.0000 \\
\hline KRUSZWIC & 0.0233 & -0.0530 & -0.0087 & -0.0134 & -0.0228 & -0.0130 \\
\hline $\boldsymbol{R}_{\boldsymbol{p}}$ & -0.3242 & -0.4224 & -0.1484 & -0.3065 & 0.3435 & $\mathbf{1 . 0 2 5 0}$ \\
\hline $\boldsymbol{W I G 2 0}$ & -0.2292 & -0.0716 & -0.1371 & -0.1676 & -0.3318 & $\mathbf{- 0 . 3 7 4 6}$ \\
\hline
\end{tabular}




\section{Conclusions}

Evaluation of the attractiveness of a sector is a difficult element of market analyzes. This is due to the complexity of the problem. Existence of many companies and a number of measures used to assess the condition of economic and financial standing, makes it difficult to analyze objectively the investment attractiveness of companies composing the stock exchange sectors. The search for the leading sector is associated with the evaluation of the following criteria: market, financial, organizational and technical. Application of the fundamental power index with some generalizations, made the financial criteria the key factors in assessing the attractiveness of a sector. These criteria are directly related to the economic and financial condition of entities in the sector. The aim of the article was to propose an objective and simple identification procedure for a given period of time, for ranking of sectors according to their investment attractiveness and the use of this information in the construction of securities portfolio. This attractiveness stems from the use of fundamental factors creating and describing the strength of companies as well as sectors they belong to. The procedure was illustrated with an example of the Warsaw Stock Exchange. The results prove the intuitive assessment of the sectors' attractiveness on the capital market in Poland, over the studied period of time. The application of the procedures of the construction of sectoral portfolio of securities proved the validity of the assumptions. In the analyzed period, results of portfolios in the capital market in Poland are above-average. The advantage of the proposed method is its universalism, and no formal limit to the number of companies in sectors or range of years covered by the analysis. The example used data from companies listed on the Warsaw Stock Exchange in years 2006-2010. This allows one to take into account the end of the bull market from 2006-2007 and the crisis of 2008-2010. The effectiveness of portfolio was carried out for the years 2011-2016 (26 IX).

\section{References}

Abad C., Thore S.A., Laffarga J. (2004), Fundamental Analysis of Stocks by Two-Stage DEA, "Managerial and Decision Economics", vol. 25, no. 5, pp. 231-241.

Arnold G. (2010), Inwestowanie w wartość, Wydawnictwo Naukowe PWN, Warszawa.

Arnot R.D., Hsu J.C., West J.M., (2008), The Fundamental Index: A Better Way to Invest, Wiley \& Sons Inc., New Jersey.

Blajer-Gołębiewska A. (2012), Stock exchanges indices and abnormal returns in the crisis condition, "Journal of International Studies", vol. 5, no. 2, pp. 9-17.

Blajer-Gołębiewska A. (2014), Corporate Reputation and Economic Performance: the Evidence from Poland, "Economics and Sociology", vol. 7, no. 3, pp. 194-207.

Bodie Z., Kane A., Marcus A.J. (2014), Essentials of Investments, $10^{\text {th }}$ ed., Mc Grow-Hill, New York. Edirisinghe N.C.P., Zhang X . (2008), Portfolio Selection under DEA-Based Relative Financial Strength Indicators: Case of US Industries, "The Journal of the Operational Research Society", vol. 59, no. 6, pp. 842-856. 
Graham B. (2007), Inteligentny inwestor, Wydawnictwo Studio EMKA, Warszawa.

Graham B., Dodd D. (2005), Security Analysis, $5^{\text {th }}$ ed., Mc Grow-Hill, New York-Toronto-London. Hagstrom R.G. (2007), Na sposób Warrena Buffeta, Wydawnictwo Naukowo-Techniczne, Warszawa. Holthausen R., Larckrer D. (1992), The Prediction of Stock Returns Using Financial Statement Information, "Journal of Accounting and Economics", vol. 15, pp. 373-411.

Mauldin J.F. (2007), Reguty giełdy, Wydawnictwo Helion, Gliwice.

Mrzygłód U., Nowak S. (2013), Stock exchanges go public. The case of Warsaw stock exchange, "Journal of International Studies", vol. 6, no. 2, pp. 111-123. doi:10.14254/2071-8330.2013/6-2/10.

Navellier L. (2007), Mała ksią̇eczka o inwestowaniu w akcje wzrostowe, MT Biznes, Warszawa.

Ou J.A., Penman S.H. (1989), Financial statement analysis and the prediction of stock returns, "Journal of Accounting and Economics", vol. 11, issue 4, pp. 295-329.

Piotroski J.D. (2000), Value investing: The use of historical financial statement information to separate winners from losers, "Journal Accounting Research", vol. 38, pp. 1-41.

Tarczyński W. (1994a), Taksonomiczna miara atrakcyjności inwestycji w papiery wartościowe, "Przegląd Statystyczny", no. 3, pp. 275-300.

Tarczyński W. (1994b), Rynki kapitałowe. Metody ilościowe, vol. I i II, Placet, Warszawa.

Tarczyński W. (1995a), Wielowymiarowa analiza porównawcza na giełdzie papierów wartościowych, [in:] Mikroekonometria w teorii i praktyce, "Zeszyty Naukowe Uniwersytetu Szczecińskiego", no. 6, pp. 171-190.

Tarczyński W., Hozer J., Gazińska M., Wawrzyniak K. (1995b), Analiza fundamentalna na giełdzie papierów wartościowych, PTE, Szczecin.

Tarczyński W., Łuniewska M. (2004), Dywersyfikacja ryzyka na polskim rynku kapitałowym, Placet, Warszawa.

Tarczyńska-Łuniewska M. (2013a), Definition and nature of fundamental strengths, "Actual Problems of Economics", vol. 2, no. 1, pp. 15-23.

Tarczyńska-Łuniewska M. (2013b), Metodologia oceny sity fundamentalnej spótek (giełdowych i pozagietdowych), ZAPOL, Szczecin.

\section{Wykorzystanie metody identyfikacji sektora wiodącego na potrzeby analizy portfelowej}

Streszczenie: Rozwój rynku giełdowego wymaga uwzględnienia wpływu wielu czynników. Znajomość całego rynku jest konsekwencją prowadzonych badań na tym rynku na różnych poziomach agregacji. Odnosząc się do sektorów należy powiedzieć, że poziom rozwoju ekonomiczno-finansowego sektora kształtuje obraz warunków ekonomicznych i rynkowych będących pochodną poziomu rozwoju podmiotów tworzących rynek. Istotna staje się możliwość zidentyfikowania sektorów wiodących lub spółek, które mają największy wpływ na rynek. Takie podejście jest ważne z kilku powodów. Jednym z nich jest proces inwestowania na rynku kapitałowym. Głównym celem opracowania jest zatem przedstawienie metody identyfikacji sektora wiodącego na rynku kapitałowym oraz wykorzystanie tej informacji w procedurze budowy portfela papierów wartościowych. Badanie zostało przeprowadzone dla Giełdy Papierów Wartościowych w Warszawie w latach 2006-2010. W analizie zostały wykorzystane wybrane informacje z zakresu czynników fundamentalnych. Wybrane czynniki zostały użyte w konstrukcji dynamicznego wskaźnika siły fundamentalnej WSF. W artykule zaproponowano prostą metodę określania sektora wiodącego. Metoda uwzględnia informacje o sile fundamentalnej spółek tworzących sektor oraz o liczbie spółek wchodzących w skład danego sektora. Na podstawie tej informacji zaproponowano procedurę budowy portfela papierów wartościowych. Dwa rodzaje portfeli skonstruowano na początek 2011 roku i zweryfikowano ich efektywność za lata 2011-2016 (IX). W wyniku przeprowadzonych badań udowodniono hipotezę, że wybór papierów war- 
tościowych do portfela z wykorzystaniem metody identyfikacji sektora wiodącego jest lepszy niż klasyczne metody analizy portfelowej.

Słowa kluczowe: analiza fundamentalna, wskaźnik siły fundamentalnej, rynek kapitałowy

JEL: G11, G31

\begin{tabular}{|l|l|}
\hline \multirow{2}{*}{ OPEN ACCESS } & $\begin{array}{l}\text { C by the author, licensee Łódź University - Łódź University Press, Łódź, Poland. } \\
\text { This article is an open access article distributed under the terms and conditions } \\
\text { of the Creative Commons Attribution license CC-BY } \\
\text { (http://creativecommons.org/licenses/by/3.0/) }\end{array}$ \\
\cline { 2 - 2 } & Received: 2016-10-24; verified: 2017-01-11. Accepted: 2017-05-23 \\
\hline
\end{tabular}

